\title{
The functionality of reward in influencing the reinforcement of performance evaluation criteria and organisational commitment among employees
}

\begin{tabular}{|c|c|}
\hline \multicolumn{2}{|c|}{$\begin{array}{l}\text { Authors: } \\
\text { Kehinde G. Somoye }{ }^{1} \text { (D) } \\
\text { Şerife Z. Eyupoglu }\end{array}$} \\
\hline \multicolumn{2}{|c|}{$\begin{array}{l}\text { Affiliations: } \\
{ }^{1} \text { Department of Business } \\
\text { Administration, Faculty } \\
\text { of Economics and } \\
\text { Administrative Sciences, } \\
\text { Near East University, } \\
\text { Nicosia, Turkey }\end{array}$} \\
\hline \multicolumn{2}{|c|}{$\begin{array}{l}\text { Corresponding author: } \\
\text { Kehinde Somoye, } \\
\text { kehindesomoye@gmail.com }\end{array}$} \\
\hline \multicolumn{2}{|c|}{$\begin{array}{l}\text { Dates: } \\
\text { Received: } 13 \text { Nov. } 2019 \\
\text { Accepted: } 03 \text { Apr. } 2020 \\
\text { Published: } 25 \text { June } 2020\end{array}$} \\
\hline \multicolumn{2}{|c|}{$\begin{array}{l}\text { How to cite this article: } \\
\text { Somoye, K.G., \& Eyupoglu, S.Z. } \\
\text { (2020). The functionality } \\
\text { of reward in influencing } \\
\text { the reinforcement of } \\
\text { performance evaluation } \\
\text { criteria and organisational } \\
\text { commitment among } \\
\text { employees. South African } \\
\text { Journal of Business } \\
\text { Management, 51(1), a1848. } \\
\text { https://doi.org/10.4102/ } \\
\text { sajbm.v51i1.1848 }\end{array}$} \\
\hline \multicolumn{2}{|c|}{$\begin{array}{l}\text { Copyright: } \\
\text { (C) 2020. The Authors. } \\
\text { Licensee: AOSIS. This wo } \\
\text { is licensed under the } \\
\text { Creative Commons } \\
\text { Attribution License. }\end{array}$} \\
\hline \multicolumn{2}{|l|}{ Read online: } \\
\hline 口itra & $\begin{array}{l}\text { Scan this QR } \\
\text { code with your } \\
\text { smart phone or } \\
\text { mobile device } \\
\text { to read online. }\end{array}$ \\
\hline
\end{tabular}

Purpose: The primary aim of this study was to provide empirical evidence on how reward can trigger employees to act in a way that is in tandem with an organisation's performance evaluation criteria in the service delivery sector. In addition, it examines how organisations can use reward to influence organisational commitment.

Design/methodology/approach: A descriptive cross-sectional survey design was adopted. Primary data were collected using a structured questionnaire targeting the employees in the Nigerian public service sector. To test its hypotheses, the study used the data collected from 522 respondents in Nigeria Local Government (LG). Data were analysed on SPSS (version 20) using regression.

Findings/results: The analysis of this study identifies reward to influence performance evaluation criteria and organisational commitment in the public service sector. The results obtained demonstrate that reward has a significant influence on organisational commitment. In addition, the reward system of an organisation was found to be a significant channel to reinforce the desired behaviours that inform performance criteria.

Practical Implications: With the findings of this study it is concluded that reward is a key variable that can help the public service sector to become more effective and efficient. However, the use of reward by managers can make performance evaluation criteria worthy of appreciation by the employees, thereby increasing organisational commitment.

Originality/value: This study revealed the dual role reward can play to influence employees' organisational commitment, and the behaviours that organisations desire to reinforce in performance evaluation criteria. This is the first study that examined this relationship.

Keywords: reward; performance evaluation criteria; organisational commitment; local government; public service sector.

\section{Introduction}

Reward refers to a potent leverage to motivate employee behaviour, a particular monetary return or event that employees receive in exchange for performed tasks in the workplace and a precondition for achieving organisational goals (Cristofori, Salvi, Beeman, \& Grafman, 2018; Gbande, 2016; Franco-Santos \& Gomez-Mejia, 2015). There are sources for rewards. Among several sources for reward (such as job, skill, seniority), according to Hamukwaya and Yazdanifard (2014), a proper performance-based reward system is fundamental. Before an employee can be rewarded, there should be an objective yardstick to it which forms the bases upon what to be rewarded. These yardsticks are called criteria. Using appropriate criteria by an employing organisation to evaluate the employees can positively affect the organisational performance (Pettijohn, Pettijohn, \& Taylor, 2000). In practice, what is evaluated are the certain behaviours required from employees to ensure that the services that bring forth performance are provided in the organisations. However, the efficiency of this evaluation mainly rests on the criteria for evaluation (Venclová, Salková, \& Kolácková, 2013). For organisations to reinforce the desired behaviours and making these behaviours to be exhibited continuously, reward is one of the needed tools (Dad, Ali, Janjua, Shahzad, \& Khan, 2010).

Organisational commitment (OC) is considered as one of the most important concepts in the area of organisational behaviour and human resource management (HRM) (Dhar, 2015). It refers to individuals' loyalty or bond to their employing organisation (Demir, Sahin, Teke, Ucar, \& Kursun, 2009). It has been a concept highly valued in every organisation that connects the employee to the 
organisation (Oyeniyi, 2013). Among many scholars, Nazir, Shafi, Qun, Nazir and Tran (2016) showed that increasing OC is linked to a good reward system. Research shows that the substantial level of reward offered by an organisation to its employees for commitment can influence the employees to be more committed. In practice, this suggests that the more frequent the reward for commitment to employees, the stronger the possibility to increase commitment.

In the service delivery sector, in which the public sector is a key player, services such as education, energy, health, security, roads, transportation, and many other services targeted at citizens, tourists, public and private companies remain part of their responsibilities. These responsibilities are channels of investment to a nation's economy in which its daily activities are to be propelled by an effective and committed large pool of human resources for good service delivery to the people. However, in Nigeria, the Local Government (LG), which is a service delivery sector, has not provided optimal services to meet the basic needs of the people at grassroots level. One of the reasons, as provided by Onyishi, Eme and Emeh (2012), is that there is an inconsiderable commitment to duty on the part of the employees. In addition, as highlighted by Simmons (2015), reward in the LG does not take into account performance as it is tainted with unfairness and nepotism. Unfortunately, due to the increase in corruption level, exhibiting good behaviours has lost relevance in the LG performance evaluation criteria. The needed commitment in the LG can occur if it administers reward appropriately to desired behaviours exhibited to given responsibilities. This, as noted by Pitt, Foreman and Bromfield (1995), can nurture employees' committment to the organisation, making them serve it better.

Studies on the relationship between reward and OC is considered less apparent in the LG and there is no study that has examined the influence reward has on performance evaluation criteria (PEC) in the service delivery sector. This is a gap that this study intends to fill. It is against this background that this study examines how organisations can use a reward system to motivate employees to act in a way that is in tandem with the organisation's PEC and how reward influences OC. The originality of this current study reveals the dual role reward can play to influence employees' $\mathrm{OC}$ and the behaviours that organisations desire to reinforce in PEC. Coupled with this is the setting of the study which is the Nigerian public service sector and no previous study has examined this relationship. This study contributes to the HRM and public service literature by revealing a deeper relationship that exists between the investigated variables, which can bring about effective public service delivery. The conceptual framework for this study is presented in Figure 1.

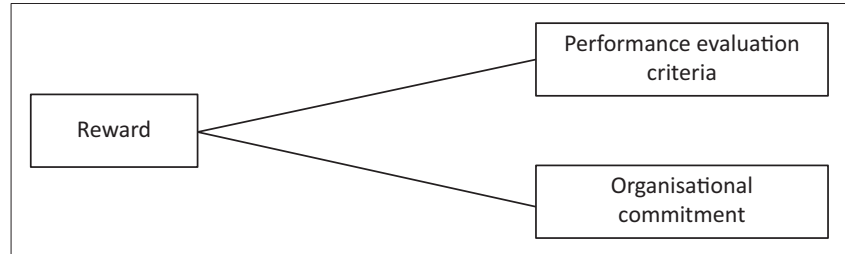

FIGURE 1: Conceptual framework.

\section{Theoretical framework and hypothesis development Reward}

In an increasingly competitive society as we have today, organisations that are passionate about their visions and missions are constantly adapting their strategies to attract, motivate and retain competent persons. An efficient reward system seems to be the best way to go about it. Reward is an organisational obligation to the employees to compensate for their contribution towards the attainment of organisational goals (Nwokocha, 2016; Saleem, 2011). Many researchers have argued that reward is the greatest source of motivation to the employees (Tsede \& Kutin, 2013; Karami, Dolatabadi, \& Rajaeepour, 2013; Nwokocha, 2016). It is known that everyone needs motivation to function effectively and efficiently. According to Armstrong (2010), reward is a form of recognition of a person's contribution. This recognition, which can be tangible or non-tangible, is on the basis of the job that such individuals do, level of their performance, competence or skill (contingent or variable pay), or for their services in the job (service-related pay) (Nwokocha, 2016). It is in view of this that an organisational reward system has to be well broadened to capture the contributions at a diverse level. The essence of this reward is such that employees can enhance the quality of their work (Mujtaba \& Shuaib, 2010). In the views of Karami et al. (2013), there are three reasons why organisations should consistently give rewards. Firstly, with a good reward system, the organisation attracts employees with the necessary competence and qualifications; secondly, the reward that is given to employees instead of service compensation is a medium to get a response from the previous performance; and thirdly, reward is a motivational tool for future performance. This implies that with reward, an organisation gets the best persons for the job and enhances the commitment of the employees.

\section{Performance evaluation criteria}

In organisations, employees are adequately informed about their roles through the job description. This job description can include, for example, responsibilities, skills and job input that relates to the specific jobs which are expected to accurately reflect a comprehensive scope expedient for employees' success in the organisation (Jacobson, Trojanowski, \& Dewa, 2012). Mader-Clark (2013) noted that job description communicates an organisation's expectation reflecting clear-cut goals. Besides, PEC can be interpreted to be similar to organisational goals (Shen, 2004). The soft goal is an example of an organisational goal that clearly explains the nature of PEC. Fekete and Rozenberg (2014) and Kang and Shen (2016) explained soft goals as work attitude and behaviour, individual performance, experience, leadership skills, interpersonal skills and customer service quality.

Furthermore, while defining performance evaluation, Seniwoliba (2014) explained it to be an evaluation process where quantitative scores are assigned to a certain employee's 
performance based on predetermined criteria. The criteria are borne out of the understanding of the relative connections they have with organisational performance. Inspiring the implementation of PEC among employees can be a positive move for an organisation for its potency to encourage employees to behave in the desired way that suits the expectations of the organisation for success. From another perspective PEC describes the common beliefs of employees accompanied by a greater degree of agreement and compliance (Saturno, Palmer, \& Gascón, 1999). When an employee has a trait or displays a behaviour naturally that favours or disfavours organisational goals, a point of confluence between the employee and employer can positively or negatively alter the future relationship between both sides. This remains one out of many reasons why criteria are needed to be clear, with both sides agreeing to it for performance evaluation.

According to Duraisingam and Skinner (2005), PEC is to be correctly identified by organisations. Also, the employees need to perceive these criteria as being relevant and applicable to their daily tasks, acceptable and fair and mutually agreed between management and employees. Participation of employees in the development of these criteria aids their perception in that it fosters cooperation between the managers and the employees, thereby preventing any future conflicts between them (Islam \& Rasad, 2006). Objectivity is one characteristic of a fair performance evaluation which is to be based on behaviours regarding some functions that are under the control of the employees (Çelik, 2014). Communication is key here. Just as communicating the result of an evaluation process to employees is important, so is the communication of PEC. As noted by Erdogan (2000), this is the duty of an employing organisation. As a fair process, these criteria are to be understood by the employees prior to the evaluation period (Erdogan, 2000). And as a matter of preference, what makes up the PEC, indicate importance and what is absent, indicate unimportance (Islam \& Rasad, 2006).

\section{Organisational commitment}

Organisations that thrive in a very competitive market do consider having committed employees as part of their human resources so as to achieve their set goals and objectives (Milgo, Namusonge, Kanali, \& Makokha, 2014). Being seen as a necessary part of the organisation creates a psychological relationship between the organisation and the employees, whereby the employees see themselves as part of a team working towards the success of the organisation (Brenda \& Onuoha, 2016; Khan et al., 2014). For both the employing organisation and the employees, it has been related to valuable outcomes that can bring about increased feelings of belonging, security, efficacy, greater career advancement, increased compensation and increased intrinsic rewards for the employees (Azeem, 2010). Its antecedents include several variables such as job satisfaction, motivation, participative decision-making, organisational support, financial reward, communication, promotion prospects and leadership (Lok \& Crawford, 2004; Salami, 2008). Coupled with this, it has been noted to be dependent on some demographic variables such as age, organisational tenure and education (Elizur \& Koslowsky, 2001).

One of the most widely accepted definitions of OC is given by Allen and Meyer (1990). They defined OC as affective (which means employees devote themselves to actions because of the desire to achieve goals in favour of their organisation), continuance (which means being calculative as an employee before taking a decision to leave an organisation an ability that creates an awareness), and normative (which is the costs that employees would have to obtain if the decision to leave an organisation is inevitable). As noted by Nehmeh (2009), OC is what sustains employees to stay in the organisation for a long tenure, makes them understand the goals and work assiduously towards meeting the targets. According to Irefin and Mechanic (2014), individuals who are less committed, are more interested in their personal success than the organisational success; in effect, they do not put their heart into the job and an opportunity elsewhere would result in their quitting their job. On the other hand, committed employees will see themselves as a part of the organisation and remain loyal to it (Permarupan, Al-Mamun, Saufi, \& Zainol, 2013). They see the success of the organisation as theirs too and any danger to the organisation is considered as a threat to them too (Irefin \& Mechanic, 2014). So OC can be seen as the extent to which the employees see themselves as part of the organisational values and missions and are committed to achieving them.

\section{Reward and performance evaluation criteria}

In the list of decisions that an average organisation makes, one of the top priorities need to be the reward system. On one side, human resources in an organisation must be paid for their work. Meanwhile, from a general point of view, it must be stated that work is not an end in itself, rather a means that gives individuals the opportunity to acquire the resources needed to enjoy their time away from the job (Wrzesniewski, McCauley, Rozin, \& Schwartz, 1997) Realistically, work is essential, nevertheless, the acquired resources can be money which is associated with employees' perception of their work. The perception may be just to be present at work regularly during the working hours, carry out the necessary tasks and get paid at the end of the month. This primarily gives employees the opportunity to afford their basic needs, go on vacations and be at leisure. On another side, employees would not only settle for a salary as they are also interested in promotion, advancement, fringe benefits, to mention a few (Dewhurst, Guthridge, \& Mohr, 2009). Correctly rewarding employees can direct them to achieve the goals of the organisation which may have an indirect influence on the quality of services delivered to the customers (Asaari, Desa, \& Subramaniam, 2019).

It is observed by Paulsen (2002) that an organisation can be a group of coordinated people working as a team to achieve a set of goals - especially the soft goals, which precisely explain 
the nature of PEC as noted previously. In order to meet these soft goals, amongst other requirements, an important one is building a team who knows the nature of the tasks to be carried out and can get them done with the appropriate behaviours for organisational performance.

In the public sector, as claimed by Verbeeten (2008), there are many managers at different levels who have multiple goals and this can complicate the criteria applied to the administration of rewards to employees. For employees' sake, the public sector has to be consistent with clear operating goals. According to Van der Hoek, Groeneveld and Kuipers (2018), having clear operating goals can help employees in knowing the expectations of the organisation and behave in a way that will make the goals achievable. In principle, when managers come to a decision that a team is needed to achieve a set of goals, each member of this team should have a strong feeling that their behaviours will be rewarded by the criteria accepted by the management. This can prompt the exhibition of behaviours to central goals and encourage not just the freedom in how these goals are achieved but also in offering rewards appropriate to it.

While at the point of hiring new employees, organisations look for some specific behaviours that are core ingredients to achieve the organisational performance. By rewarding these behaviours, new or incumbent employees are routinely reminded of the goals of the organisation and how to achieve them. By so doing, these behaviours become criteria to evaluate the employees.

The relationship between reward and PEC was clearly understood when viewed under the lens of Skinner's theory. According to the theorists, Luthans and Kreitner (1985), four behaviourally oriented strategies were proposed by Skinner to shape employees' behaviours. They are positive reinforcement, negative reinforcement, punishment and extinction (Luthans \& Kreitner, 1985). This study focuses on the first, which is positive reinforcement. It was said that behavior reinforced by a reward is likely to be repeated (Scott \& Cogburn, 2017). For instance, an employee who is rewarded for punctuality or innovation at the workplace will put more effort into this behaviour. One of the main functions of performance evaluation is that it describes the behaviour that is desired, coupled with an observation of employees' true behaviour (Šišinački, Dobiš, \& Šišinački, 2017).

In other words, when organisations create the appropriate climate of organisational support such as rewards, they reinforce these desired behaviours among employees. Failure of an organisation to identify, design and roll out a reward system will automatically and purposely reinforce undesirable behaviour among employees. The effectiveness of PEC depends on how just, well and fair organisations reward their employees. The reason for an employee to have low ratings in performance may be because of the poor reward system of the organisation. In the following sequence, this study proposes the following hypthesis:
H1: The reward system of an organisation is a channel to reinforcing the desired behaviours that inform PEC

\section{Reward and organisational commitment}

While a myriad of studies have shown a strong correlation between an organisational rewarding system and OC (Eisenberger \& Stinglhamber, 2011; Malhotra, Budhwar, \& Prowse, 2007; Mabaso \& Dlamini, 2018; Milgo et al., 2014; Nazir et al., 2016), there has been no comprehensive study that proves otherwise. Korir and Kipkebut (2016) examined the effect of reward management on employees' commitment in the universities. The study found that financial reward management practices collectively have a significant effect on OC. While examining the effect of reward practices on employee commitment, Okinyi (2015) assessed the reward policies put in place by faith-based health organisations to enhance employees' commitment and also examined the effect of intrinsic rewards on employees' commitment in the organisation. It was revealed that there is a strong relationship, and the better the practice, the more committed employees will be to the organisation. Similarly, Brenda and Onuoha (2016), while examining the relationship between dimensions of reward management strategies (pay structures and employee benefits) and the indicators of OC (affective and continuance commitment), the findings showed a positive relationship between reward management strategies and OC. It was concluded that the implementation of pay structures and employee benefits significantly enhances OC (affective and continuance commitment). Ahmed, Ismail, Amin, Ramzan and Khan (2012) and Smyth and Zimba (2019) describe reward to organisational support and employees always try to give their best in the form of commitment to return this support.

However, in this section, this study intends to understand how the Social Exchange Theory (SET) is applied in this relationship. Previously, this theory has been used in health care (Guo, Guo, Fang, \& Vogel, 2017; Nazir, Qun, Hui, \& Shafi, 2018), social psychology (Chernyak-Hai \& Rabenu, 2018; Wikhamn \& Hall, 2012), business (Jeong \& Oh, 2017), and marriages (Sabatelli, Lee, \& Ripoll-Núñez, 2018), to mention a few. Its main foundation emphasised on the assumption that purposive actors engage and nurture relationships according to the belief that rewards will be beneficial (Zafirovski, 2005). The exchange relationship between two or more actors, which can be a worker and an organisation, is the core concern of SET. An exchange takes place within an environment where there are interaction, allowing actors to manage resources that are valued by other actors (Molm, Takahashi, \& Peterson, 2000; Nunkoo, 2016). In addition, in the exchange for criteria such as innovativeness, communication or reliability in service delivery, employees anticipate organisational support such as rewards. Similarly, organisations expect employees to perform with desirable results in exchange for rewards. According to Lin, Chiu and Liu (2019), SET puts forward that provision for reward should be done appropriately to enhance performance. This stems from the fact that as employees gain the support of 
their employing organisation, they feel obligated to embrace the norm of reciprocity for this support by ensuring that they become a better performer for effective organisational performance (Tokay \& Eyupoglu, 2018). Quite plainly, an organisationally committed employee is expected to be a better performer (Al Zefeiti \& Mohamad, 2017).

Employees are the human resources that evaluates the favourable and unfavourable factors in the organisation before taking action. For example, the voluntary exchange of symbolic resources takes place when employees understand that there are benefits attached, according to Hsu, Yin and Huang (2017). This is the norm of reciprocity, and as affirmed by Sungu, Weng and Kitule (2019), it plays a significant role in strengthening the social framework. According to Brown and Roloff (2015), organisational support will strengthen an employee's belief that the organisation recognises and rewards increased performance. More so, favourable opportunities for rewards serve to communicate a positive valuation of employees' contributions. This enables employees to interpret the organisational value and become committed to it.

On the authority of SET theorists, it has been proposed that a reward brings forth greater commitment from employees, which has a positive effect on their future engagement toward organisational goals (Tsai \& Kang, 2019). Reward systems exist with a specific long-run objective to motivate employees to work towards the achievement of organisational goals (Abbah, 2014; Anku, Amewugah, \& Glover, 2018). This is possible when the reward system has brought about commitment in the employees. In the study of Osemeke (2016), it was identified that OC is greatly influenced by the type of reward that the employees receive. Also, employees' commitment to their organisation is enhanced by the use of a profit-sharing arrangement (Long, 2000; Osemeke, 2016), which is a system with the intent of returning to the employees a share of the fruits of their collective labour (Coyle-Shapiro, Morrow, Richardson, \& Dunn, 2002).

By utilising SET to examine the relationship between reward and $\mathrm{OC}$, the evidence shows that better understanding is obtained with regard to the reason why employees increase their OC with a good reward practice. A social exchange relationship suggests obligation and rights on the organisation and its employees (Liu, Loi, \& Ngo, 2018). The employing organisation should offer rewards to its employees, in exchange for their commitment. Based on this premise, this study proposes the following hypothesis:

H2: Organisation reward practice positively influences OC among employees

\section{Methodology Data collection and measurement}

The primary data used in this study was gathered via administration of a structured questionnaire. This questionnaire was administered to LG employees in two states in Nigeria. Local government workers represent a part of the workforce under the Nigerian public service sector.
Several studies that have been carried out to examine the public sector have also used LG employees as respondents of their surveys (Sam-Okere \& Agbeniga, 2014). There are six states in the Southwest region of Nigeria. A multistage sampling technique was used in the process of selecting the states used for this survey. Two out of the six states were selected, namely Ekiti State and Osun State. Ekiti state has 16 LGs while Osun State has 30 LGs. In Ekiti state the three biggest LGs were selected with a total population of 2471 employees and in Osun State the seven largest LGs were selected with a total population of 1951 employees. At the time this study was carried out, as released by the Director of Personnel Management of the 10 LGs, the total population was 4422. For this population size, according to Krejcie and Morgan (1970), 354 is suitable at $\pm 5 \%$ precision level and 95\% confidence level. A stratified sampling technique was adopted to select the employees to participate in the survey. There are nine departments in the LGs in the two states used for this study and they are administration and general services, budget and planning, finance and supply, agriculture and food security, works, water and environmental sanitation, town and regional planning, social and community development, and primary health care. Each department of the LG formed a stratum. To have a robust result, 600 copies of questionnaires were administered in the 10 LGs and 525 copies were collected from the field of survey. The respondents were at ease with the objectives of the study due to the simplicity of each item of the questionnaire. The respondents were offered gifts worth 2 USD each to motivate them to voluntarily respond to the items of the questionnaire. The questionnaire had a cover page on which they were informed of the researchers' strict adherence to the rules of confidentiality and anonymity. No one was forced to attempt the questionnaire and anyone who was no longer interested to continue the survey was allowed to opt out.

The questionnaire that was used for this study was designed according to the literature review of this study. All the constructs in the questionnaire were measured using existing scales. The reward items were adapted from the study of Kassabgy, Boraie and Schmidt (2001), OC from the study of Meyer and Allen (1997) and PEC from the study of Othman (2014). Also, some items were edited to suit the tonality of this study. In OC items 'organisation' was replaced with 'LG'. For example, 'The setting of our Local Government is comfortable'. For PEC, the initial construct was, for example, 'Job Knowledge' and it was reconstructed to be 'I am evaluated based on Job knowledge'. The items for reward were not edited and they were used just as it was adapted. All the items were on a Likert scale ranging from strongly agree (1) to strongly disagree (5). The questions in the questionnaire were sectioned into two. The first section of the questionnaire contained all the items related to reward, PEC and OC variables, and they were mixed. No identification of sections for each variable was done so as to avoid common method variance. The second section contained the demographic variables. It was placed as the second section 
so as to avoid social desirability response since it contains some personal information needed for this study. After data were collected, they were transferred to an SPSS spreadsheet and from inspections, there were no extreme figures. Afterwards, the Mahalanobis distance was calculated through SPSS to identify multivariate outliers and from inspections three (3) values were observed to be lower than the $p$-value $(p<0.001)$. These three (3) responses were completely removed from the dataset, leaving 522 responses for the study's analysis. The descriptive information for the demographic variables as shown in Table 1 reveal that more than half of the respondents are female $(52.3 \%)$ while the respondents in the age group of 41 - 50 years $(36.4 \%)$ are above one third. The respondents with 11-15 years length of service are $28.5 \%$. The majority are Bachelor's degree holders (52.7\%).

\section{Analysis and results}

The existing items for each of the variables of the study were subjected to principal factor analyses to ascertain if the items loaded appropriately. Based on the result, items that had a factor loading above 0.40 are retained and Table 2 presents the reliability for these retained items, which are all acceptable. Common method bias was checked through Harman's single-factor test. The single factor accounted for $20.1 \%$, which invariably accounts for a minority of the variance in the model of this study.

TABLE 1: Descriptive statistics of the demographic variables.

\begin{tabular}{llcc}
\hline Variable & Options & Frequency & Percentage \\
\hline Gender & Male & 249 & 47.7 \\
& Female & 273 & 52.3 \\
Age & 30 years and below & 112 & 21.5 \\
& 31-40 years & 163 & 31.2 \\
& $41-50$ years & 190 & 36.4 \\
& 51-60 years & 55 & 10.5 \\
Length of Service & 1-5 years & 2 & 0.4 \\
& 6-10 years & 130 & 24.9 \\
& $11-15$ years & 89 & 17.0 \\
& $1-20$ years & 149 & 28.5 \\
Education & 21 years and above & 110 & 21.1 \\
& BSc & 44 & 8.4 \\
& MA/MSc & 275 & 52.7 \\
& M.Phil & 40 & 7.7 \\
& PhD & 22 & 4.2 \\
& Others & 6 & 1.1 \\
\hline
\end{tabular}

BSc, Bachelor of Science; MA/MSc, Master of Arts/Master of Science; M.Phil, Master of Philosophy; PhD, Doctor of Philosophy.

TABLE 2: Post reliability report.

\begin{tabular}{lcc}
\hline Variable & Number of retained items & New Cronbach's Alpha \\
\hline OC & 3 & \\
Affective & 3 & 0.83 \\
Continuance & 6 & 0.57 \\
Sub total & 5 & 0.70 \\
Reward & 12 & 0.75 \\
PEC & - & 0.84 \\
Total & 0.75 \\
\hline
\end{tabular}

OC, organisational commitment; PEC, performance evaluation criteria.
Table 3 presents the descriptive information on the perception of the employees concerning the criteria their employing organisation base their performance evaluation on. Analysis of the mean scores of PEC shows that employees perceived all the criteria to be important as they agreed to being evaluated on their bases. However, reliability (mean $=1.95$, $\mathrm{SD}=0.77$ ), behaviours (mean $=2.01, \mathrm{SD}=0.92$ ) and work management $($ mean $=2.08, \mathrm{SD}=0.86)$ had the highest scores, respectively.

\section{Results: Test of relationship}

The correlation statistics are presented in Table 4 with two levels of significance $(p=0.05$, and $p=0.01)$. It was discovered that reward and OC are significantly and positively correlated $(r=0.36, p<0.01)$. Reward and PEC are also significantly and positively correlated $(r=0.18, p<0.01)$. All of the controlled variables except age were observed to correlate with other variables. They were used in the subsequent regression models of study variables.

\section{Results: Test of regression analysis}

Using regression analysis, based on 522 entries, the two hypotheses of this study were tested and Tables 5 and 6 present the regression analysis results. As shown in Table 5 the PEC was regressed on the controlled variables and reward with results in model 1 and 2 respectively. In model 1 , none of the controlled variables significantly affected PEC. In model 2 rewards were introduced and only gender was observed to affect PEC $(b=0.09, p<0.05)$. However, reward was observed to influence PEC $(b=0.19, p<0.001)$. The $\mathrm{R}^{2}$ (0.05) revealed that $5 \%$ of the variance in PEC could be explained by the variance in the reward. It can be said that most influence that is experienced by PEC does not come from rewards alone, but also from gender, even though it has a small contribution. Hence, hypothesis 1 was supported, which states that the reward system of an organisation is a channel to reinforce desired behaviours that inform PEC.

As shown in Table 6, OC was regressed on the controlled variables and reward. In model 1, regarding the controlled variables, organisational tenure and education negatively and positively affected organisational commitment respectively $(b=-0.09, p<0.05$ and $b=0.09, p<0.05)$. The $\mathrm{R}^{2}(0.02)$ revealed that $2 \%$ of the variance in OC could be explained by the

TABLE 3: Employee perception on performance evaluation criteria.

\begin{tabular}{lcc}
\hline Items & Mean & Standard deviation \\
\hline Reliability & 1.9518 & 0.77334 \\
Behaviour & 2.0116 & 0.92366 \\
Work management & 2.0751 & 0.86331 \\
Communication & 2.0809 & 0.85492 \\
Decision-making & 2.0906 & 0.92242 \\
Innovativeness & 2.0983 & 0.90685 \\
Ability to receive instruction from superior & 2.1252 & 0.92463 \\
Ability to understand & 2.1252 & 0.91624 \\
Ability to finish work on time & 2.1464 & 0.92673 \\
Handling office equipment & 2.1676 & 0.93662 \\
Leadership & 2.2697 & 1.08360 \\
Interpersonal relations & 2.4066 & 1.06653 \\
\hline
\end{tabular}


TABLE 4: Correlation analysis.

\begin{tabular}{lcccccccc}
\hline Variables & Mean & SD & $\mathbf{1}$ & $\mathbf{2}$ & $\mathbf{3}$ & $\mathbf{4}$ & $\mathbf{5}$ \\
\hline OC (1) & 3.16 & 0.60 & 1 & - & - & - & - \\
Reward (2) & 2.77 & 0.86 & $0.363^{* *}$ & 1 & - & - & - \\
PEC (3) & 2.14 & 0.56 & $0.147^{* *}$ & $0.179 * *$ & 1 & - & - \\
Age (4) & 2.37 & 0.95 & 0.018 & 0.011 & 0.042 & 1 & - \\
Gender (5) & 1.52 & 0.50 & -0.004 & -0.051 & $0.092^{*}$ & $-0.107^{*}$ & 1 \\
Length of Service (6) & 2.71 & 1.28 & $-0.088^{*}$ & -0.024 & 0.022 & $0.634^{* *}$ & -0.078 & - \\
Education (7) & 2.57 & 1.84 & $0.087^{*}$ & 0.073 & 0.048 & -0.074 & -0.062 & -0.028 \\
\hline
\end{tabular}

$\mathrm{OC}$, organisational commitment; PEC, performance evaluation criteria.

*, Correlation is significant at the 0.05 level (2-tailed); **, Correlation is significant at the 0.01 level (2-tailed).

TABLE 5: Regression analysis of the influence of reward on performance evaluation criteria.

\begin{tabular}{|c|c|c|c|c|c|c|}
\hline Variable & $R$ & $R^{2}$ & $d f$ & $F$ & $t$ & $\beta$ \\
\hline Model 1 & 0.109 & 0.01 & 518 & 2.059 & - & - \\
\hline Gender & - & - & - & - & 1.937 & 0.085 \\
\hline Organisational tenure & - & - & - & - & 0.620 & 0.027 \\
\hline Education & - & - & - & - & 1.616 & 0.071 \\
\hline Model 2 (PEC) & 0.222 & 0.05 & 518 & $6.675 * * *$ & - & - \\
\hline Gender & - & - & - & - & 2.179 & $0.094 *$ \\
\hline Organisational tenure & - & - & - & - & 0.747 & 0.032 \\
\hline Education & - & - & - & - & 1.334 & 0.058 \\
\hline Reward & - & - & - & - & 4.505 & $0.194 * * *$ \\
\hline
\end{tabular}

PEC, performance evaluation criteria.

*, Correlation is significant at the 0.05 level (2-tailed); **, Correlation is significant at the 0.01 level (2-tailed); ***, Correlation is significant at the 0.001 level (2-tailed).

TABLE 6: Regression analysis of the influence of reward on organisational commitment.

\begin{tabular}{|c|c|c|c|c|c|c|}
\hline Variable & $R$ & $R^{2}$ & $d f$ & $F$ & $T$ & $\beta$ \\
\hline Model 1 & 0.125 & 0.02 & 518 & $2.736 *$ & - & - \\
\hline Gender & - & - & - & - & -0.249 & -0.011 \\
\hline Organisational tenure & - & - & - & - & -2.006 & $-0.088^{*}$ \\
\hline Education & - & - & - & - & 1.969 & $0.086^{*}$ \\
\hline Model 2 (OC) & 0.380 & 0.144 & 518 & $21.642 * * *$ & - & - \\
\hline Gender & - & - & - & - & 0.139 & 0.006 \\
\hline Organisational tenure & - & - & - & - & -1.923 & -0.079 \\
\hline Education & - & - & - & - & 1.503 & 0.062 \\
\hline Reward & - & - & - & - & 8.783 & $0.360 * * *$ \\
\hline
\end{tabular}

OC, organisational commitment.

*, Correlation is significant at the 0.05 level (2-tailed); **, Correlation is significant at the 0.01 level (2-tailed); ***, Correlation is significant at the 0.001 level (2-tailed).

variance in the organisational tenure and education. This implies that most influence that is experienced by OC does not come from the controlled variables, even though their contribution is minimal. Introducing rewards in model 2, none of the controlled variables affected OC. However, rewards were observed to significantly predict OC $(b=0.36, p<0.001)$. The $\mathrm{R}^{2}(0.14)$ shows that $14 \%$ of the variance in OC could be explained by the variance in rewards. Hence, hypothesis 2 was supported, which states that the reward practice of organisation influences OC among employees.

\section{Discussion}

In this cross-sectional study based on LG employees, the important objective was to present more grounds for understanding how reward positively influences the behaviours that organisations desire to reinforce in PEC and how reward influences OC. The discussion of the findings of this study is presented below.

The results of this study showed that reward significantly influences OC. The public service sector needs to give commensurate reward to their employees in exchange for their services. A lot of empirical findings have given credence to the fact that reward greatly influences organisational commitment. For instance, Chen, Yang, Gao, Liu and De Gieter (2015), Danish and Usman (2010), Korir and Kipkebut (2016), Mabaso and Dlamini (2018), Miao, Newman, Sun and Xu (2013), Paşaoğlu (2015), Taba (2018) found that reward was positively related to OC. This relationship may be due to the strategies of recognition and appreciation of employees based on either their behaviours, performance or both. An average employee will not work for free and this means that reward can be a signal for an employee to know how well he/she is contributing to the resultant performance of the LG service delivery. Rewarding employees, not only in the monetary form but also in non-monetary forms via expression or statement of gratitude or by offering greater responsibility, can increase their commitment. Nonetheless, a positive relationship was established by the result of this study, which simply means that higher reward will bring about increasing employee commitment. This implies that incumbent employees are retained coupled with substantial overall organisational performance. 
Accordingly, the organisational reward is essential for the actualisation of the essence of the primal idea of PEC, a proactive behaviour, amongst the employees. Based on the findings of this study, it was found that reward influenced PEC positively. This is because organisational goals require some attitudes and behaviours that are essential to attain set objectives. Due to this they become part of the criteria to reward performance. In short, these attitudes and behaviours are seen, recognised and harvested by the organisation from their employees because they reward it.

The public sector has set objectives which are accomplished through employees displaying some required abilities. Additionally, they know these abilities and their employees are evaluated based on them, coupled with a reward attached to it. Having a reward system that is openly rolled out fairly and justly to employees who perform well can increase the dexterity in expressing expected and demanded abilities towards subordinates and tasks assigned to them. In other words, rewarding employees can be a medium to ensure that the public sector gets the specific types of behaviour they are looking for. As a tool to direct these behaviours for organisational benefits, managers use them as criteria for performance evaluation. However, according to the equity theory, when employees observe an imbalance in the reward for their input (which reflects the criteria for performance evaluation), the more distress they may experience in the form of anger (Al-Zawahreh \& Al-Madi, 2012). In support of this observation, Maicibi (2003) stated that rewards should generally be commensurate to employees' job input.

The Nigerian public sector rewards employees who have the required knowledge about their job, show a high level of honesty and trustworthiness, coupled with reliability under pressure, and display good behaviour and a high level of commitment. These are classed as the top five most important criteria perceived by the respondents of this study, which is a mirror of what the public sector rewards most since it is key to excel in service delivery. It does not mean that the public sector does not reward skills like the ability to handle office equipment, leadership skills or interpersonal relations (which are the three criteria of least importance), but this order speaks volumes of what they want most from their employees. Hence, the positive relationship established in this study points out that the most important criteria in performance evaluation is what the Nigerian public sector places preference on in terms of values and reward.

\section{Conclusion}

From a theoretical perspective, this study enriches the understanding of Skinner's theory of reinforcement (Skinner, 1969) and SET in the context of the public service sector. Firstly, this study validates the reinforcement theory which gained its support in the established link between reward and PEC. It can be deduced that the higher the rewards, the more the behaviours that organisations desire to reinforce in PEC. Secondly, this showed how SET can be applied to have a deeper understanding of the functions of reward influencing commitment. It was emphasised in this study that the need to have a good reward system for employees will herald the possibility for a desirable outcome such as the commitment of employees to their organisation.

From a managerial perspective human resource managers in the Nigerian public sector need to know which criteria are appropriate and also ensure their employees are aware of these criteria that would be used to carry out the performance evaluation and influence their rewards. An organisation should be meticulous and flexible to juxtapose their required evaluation criteria with the observed performance of the employees. This brings about feedback and extensive review that is satisfactory, thereby allowing a fair and just reward system. A public sector that wants to satisfy their customers needs to identify the most important attitudes and behaviours inherent in their employees and create an evaluation system that adopts these attitudes and behaviours as criteria to be evaluated and rewarded. This will bring about good service delivery to the service consumers.

Nevertheless, managers need to understand that what is rewarded will be repeated irrespective of the capacity, responsibility and level the good employees occupy in the public sector. This can cause a causal sequence in the organisation that will yield positive results especially when the salient use of these attitudes and behaviours are within the scope of the evaluation criteria. In as much as the public sector understands the importance of commitment, reward can be utilised to influence it. Fair and just reward attached to impressive competencies makes OC increase among the employees. Managers in the public sector can seize this opportunity because it turns out to be a channel of relevant work efficiency of the employees. In addition, managers can class reward as a germane factor of current OC programs in their organisations, for it has the potential to foster the progress factor in line with the performance of employees.

\section{Limitations}

While this study was carried out, the researchers were faced with some limitations which include the characteristics of the respondents in the population and the sample size. The pool of the respondents was drawn from employees in LG with a small sample size. Coupled with this is the problem of common method bias. The items of the questionnaire used for the survey of this study were mixed and the collected data was self-reported. However, the research design was cross-sectional. We suggest that future studies can use a longitudinal or experimental design to get a better result.

\section{Acknowledgements}

This work is based on the doctorate degree dissertation of K.G.S. titled 'Examining the effect of human resources practices on organisational commitment in the Nigerian public service sector', which will be submitted (planned date of completion: June 2020) to the Near East University, North Cyprus. The coauthor of this article is the supervisor of the dissertation. 


\section{Competing interests}

The authors declare that they have no financial or personal relationships that may have inappropriately influenced them in writing this article.

\section{Authors' contributions}

Both the authors contributed equally to the planning, researching, structuring, writing and the revision of the manuscript.

\section{Ethical consideration}

This article followed all ethical standards for a research without direct contact with human or animal subjects

\section{Funding information}

This research received no specific grant from any funding agency in the public, commercial or not-for-profit sectors.

\section{Data availability statement}

Data sharing is not applicable to this article as no new data were created or analysed in this study.

\section{Disclaimer}

The views and opinions expressed in this article are those of the authors and do not necessarily reflect the official policy or position of any affiliated agency of the authors.

\section{References}

Abbah, M.T. (2014). Employee motivation: The key to effective organization management in Nigeria. IOSR Journal of Business and Management, 16(4), 1-8. https://doi.org/10.9790/487X-16410108

Ahmed, I., Ismail, W.K.W., Amin, S.M., Ramzan, M., \& Khan, M.K. (2012). Theorizing antecedents of perceived organization support: A literature review approach. Middle-East Journal of Scientific Research, 12(5), 692-698. https://doi.org/ 10.5829/idosi.mejsr.2012.12.5.2579

Allen, N.J., \& Meyer, J.P. (1990). Organizational socialization tactics: A longitudinal analysis of links to newcomers' commitment and role orientation. Academy of Management Journal, 33(4), 847-858. https://doi.org/10.5465/256294

Al-Zawahreh, A., \& Al-Madi, F. (2012). The utility of equity theory in enhancing organizational effectiveness. European Journal of Economics, Finance and Administrative Sciences, 46(3), 159-169.

Al Zefeiti, S.M.B., \& Mohamad, N.A. (2017). The Influence of organizational commitment on Omani public employees' work performance. International Review of Management and Marketing, 7(2), 151-160.

Armstrong, M. (2010). Armstrong's handbook of reward management practice: Improving performance through reward. London: Kogan Page Publishers.

Anku, J.S., Amewugah, B.K., \& Glover, M.K. (2018). Concept of reward management, reward system and corporate efficiency. International Journal of Economics, Commerce and Management, 6(2), 627-637.

Azeem, S.M. (2010). Job satisfaction and organizational commitment among employees in the Sultanate of Oman. Psychology, 1(04), 295-299. https://doi: 10.4236/psych.2010.14038

Asaari, M. H. A. H., Desa, N. M., \& Subramaniam, L. (2019). Influence of Salary, Promotion, and Recognition toward Work Motivation among Government Trade Agency Employees. International Journal of Business and Management, 14(4), 48-59. https://doi.org/10.5539/ijbm.v14n4p48

Brenda, K., \& Onuoha, B.C. (2016). Reward management strategies and organizational commitment in the banking industry in Yenagoa, Bayelsa state. International Journal of Advanced Academic Research/Social and Management sciences, 2(8), 104-117.

Brown, L.A., \& Roloff, M.E. (2015). Organizational citizenship behaviour: Organizational communication, and burnout: The buffering role of perceived organizational support and psychological contracts. Communication Quarterly, 63(4), 384-404. https://doi.org/10.1080/01463373.2015.1058287
Çelik, D.A. (2014). Enabling more objective performance appraisals: A training program model of pinpointing. Procedia-Social and Behavioral Sciences, 150 794-802. https://doi.org/10.1016/j.sbspro.2014.09.088

Chen, F., Yang, M., Gao, W., Liu, Y., \& De Gieter, S. (2015). Impact of satisfactions with psychological reward and pay on Chinese nurses' work attitudes. Applied Nursing Research, 28(4), e29-e34. https://doi.org/10.1016/j.apnr.2015.03.002

Chernyak-Hai, L., \& Rabenu, E. (2018). The new era workplace relationships: Is social exchange theory still relevant? Industrial and Organizational Psychology, 11(3), 456-481. https://doi.org/10.1017/iop.2018.5

Coyle-Shapiro, J.A.M., Morrow, P.C., Richardson, R., \& Dunn, S.R. (2002). Using profit sharing to enhance employee attitudes: A longitudinal examination of the effects on trust and commitment. Human Resource Management: Published in Cooperation with the School of Business Administration, The University of Michigan and in alliance with the Society of Human Resources Management, 41(4), 423-439. https://doi.org/10.1002/hrm.10052

Cristofori, I., Salvi, C., Beeman, M., \& Grafman, J. (2018). The effects of expected reward on creative problem solving. Cognitive, Affective, \& Behavioral Neuroscience, 18(5), 925-931. https://doi.org/10.3758/s13415-018-0613-5

Dad, H., Ali, R., Janjua, M.Z.Q., Shahzad, S., \& Khan, M.S. (2010). Comparison of the frequency and effectiveness of positive and negative reinforcement practices in schools. Contemporary Issues in Education Research, 3(1), 127-136. https://doi. org/10.19030/cier.v3i1.169

Danish, R.Q., \& Usman, A. (2010). Impact of reward and recognition on job satisfaction and motivation: An empirical study from Pakistan. International Journal of Business and Management, 5(2), 159-167. https://doi.org/10.5539/ijbm.v5n2p159

Demir, C., Sahin, B., Teke, K., Ucar, M., \& Kursun, O. (2009). Organizational commitment of military physicians. Military medicine, 174(9), 929-935. https://doi. org/10.7205/MILMED-D-01-7808

Dewhurst, M., Guthridge, M., \& Mohr, E. (2009). Motivating people: Getting beyond money. McKinsey Quarterly, 1(4), 12-15.

Dhar, R.L. (2015). Service quality and the training of employees: The mediating role of organizational commitment. Tourism Management, 46, 419-430. https://doi. org/10.1016/j.tourman.2014.08.001

Duraisingam, V., \& Skinner, N. (2005). Performance appraisal. In N. Skinner A.M. Roche, J.O'Connor, Y. Pollard, \& C. Todd (Eds.), Workforce development TIPS (Theory into practice strategies): A resource kit for the alcohol and other drugs field. Adelaide: National Centre for Education and Training on Addiction (NCETA), Flinders University.

Eisenberger, R., \& Stinglhamber, F. (2011). Perceived organizational support: Fostering enthusiastic and productive employees. Washington, DC: APA Books.

Elizur, D., \& Koslowsky, M. (2001). Values and organizational commitment. International Journal of Manpower, 22(7), 593-599. https://doi.org/10 1108/01437720110408967 Erdogan, B. (2000). Antecedents and consequences of justice perceptions in performance appraisals. Human Resource Management Review, 12(4), 555-578. https://doi.org/10.1016/S1053-4822(02)00070-0

Fekete, M., \& Rozenberg, I. (2014). The practical model of employee performance evaluation. In Human capital without borders: Knowledge and learning for quality of life; Proceedings of the Management, Knowledge and Learning International Conference (MakeLearn), Portoroz Slovenia, 25-27 June 2014. pp. 141-149.

Franco-Santos, M., \& Gomez-Mejia, L. (2015). Reward systems. Human Resource Management, 1-6. https://doi.org/10.1002/9781118785317.weom050102

Gbande, R. (2016). Effects of reward system on productivity in the local government system in Benue state. Journal of Economics and Sustainable Development, 7(22), 202-210.

Guo, S., Guo, X., Fang, Y., \& Vogel, D. (2017). How doctors gain social and economic returns in online health-care communities: A professional capital perspective. returns in online health-care communities: A professional capi
Journal of Management Information Systems, 34(2), 487-519.

Hamukwaya, S.I., \& Yazdanifard, R. (2014). How a proper performance related reward system can contribute to work performance excellence. Open Journal of Business and Management, 2(03), 189-194. https://doi.org/10.4236/ojbm.2014.23023

Hsu, C., Yin, C.P., \& Huang, M.F. (2017). Understanding exchangers' attitudes and intentions to engage in Internet bartering based on SET and TRA. Internationa Journal of Business and Information, 12(2), 149-182. https://doi.org/10.6702/ ijbi.2017.12.2.3

Irefin, P., \& Mechanic, M. (2014). Effect of employee commitment on organizational performance on Coca Cola Nigeria limited Maiduguri, Borno State. IOSR Journal of Humanities and Social Science, 19(3), 33-41. https://doi.org/10.9790/083719313341

Islam, R., \& bin Mohd Rasad, S. (2006). Employee performance evaluation by the AHP: A case study. Asia Pacific Management Review, 11(3), 1-16.

Jacobson, N., Trojanowski, L., \& Dewa, C.S. (2012). What do peer support workers do? A job description. BMC Health Services Research, 12(1), 205-216. https://doi org/10.1186/1472-6963-12-205

Jeong, M., \& Oh, H. (2017). Business-to-business social exchange relationship beyond trust and commitment. International Journal of Hospitality Management, 65, 115-124.

Kang, H., \& Shen, J. (2016). International performance appraisal practices and approaches of South Korean MNEs in China. The International Journal of Human Resource Management, 27(3), 291-310. https://doi.org/10.1080/09585192. 2015.1039562

Karami, A., Dolatabadi, H.R., \& Rajaeepour, S. (2013). Analyzing the effectiveness of reward management system on employee performance through the mediating role of employee motivation, case study: Isfahan regional electric company. International Journal of Academic Research in Business and Social Sciences, 3(9), 327-338. https://doi.org/10.6007/IJARBSS/v3-i9/214 
Kassabgy, O., Boraie, D., \& Schmidt, R. (2001). Values, rewards, and job satisfaction in ESL/EFL. In Z. Dornyei \& R. Schmidt (Eds.), Motivation and second language acquisition (pp. 213-237). Honolulu: University of Hawaii, National Foreign acquisition (pp. 213-237)
Language Resource Center.

Khan, F., Rasli, A.M., Yusoff, R.M., Ahmed, T., ur Rehman, A., \& Khan, M.M. (2014). Job rotation, job performance, organizational commitment: An empirical study on bank employees. Journal of Management Info, 1(3), 10-13. https://doi. org/10.31580/jmi.v3i1.8

Korir, I \& Kipkebut, D (2016). The effect of reward management on employee's commitment in the universities in Nakuru county - Kenya. Journal of human Resources Management, 4(4), 37-48. https://doi.org/10.11648/j.jhrm.2016 0404.12

Krejcie, R.V., \& Morgan, D.W. (1970). Determining sample size for research activities. Educational and Psychological Measurement, 30(3), 607-610. https://doi.org/10. $1177 \% 2 F 001316447003000308$

Lin, C.P., Chiu, C.K., \& Liu, N.T. (2019). Developing virtual team performance: An integrated perspective of social exchange and social cognitive theories. Review of Managerial Science, 13(4), 671-688. https://doi.org/10.1007/s11846-0170261-0

Liu, Y., Loi, R., \& Ngo, H.Y. (2018). Linking organizational social exchange to intention to leave: Does normative commitment matter? The International Journal of Human Resource Management, 1-21. https://doi.org/10.1080/09585192.2017. 1423097

Lok, P., \& Crawford, J. (2004). The effect of organisational culture and leadership style on job satisfaction and organisational commitment: A cross-national comparison. Journal of Management Development, 23(4), 321-338. https://doi.org/10.1108/ 02621710410529785

Long, R. (2000). Employee profit sharing: Consequences and moderators. Relation Industrielles/Industrial Relations, 55(3), 477-504.

Luthans, F., \& Kreitner R. (1985). Organizational behavior modification and beyond Glenview, IL: Scott, Foresman.

Mabaso, C.M., \& Dlamini, B.I. (2018). Total rewards and its effects on organisational commitment in higher education institutions. South African Journal of Human Resource Management, 16(1), 1-8. https://doi.org/10.4102/sajhrm. v16i0.913

Mader-Clark, M. (2013). The job description handbook. California: Nolo Publishing Company.

Maicibi, N.A. (2003). Pertinent issues in employees management. Kampala: MPK Graphics (U) Ltd

Malhotra, N., Budhwar, P., \& Prowse, P. (2007). Linking rewards to commitment: An empirical investigation of four UK call centres. The International Journal of Human Resource Management, 18(12), 2095-2128. https://doi.org/10.1080/09585190 701695267

Meyer, J.P., \& Allen, N.J. (1997). Commitment in the workplace. Theory, research and application. Thousand Oaks, CA: Sage.

Miao, Q., Newman, A., Sun, Y., \& Xu, L. (2013). What factors influence the organizational commitment of public sector employees in China? The role of organizational commitment of public sector employees in China? The role of
extrinsic, intrinsic and social rewards. The International Journal of Human Resource Management, 24(17), 3262-3280. https://doi.org/10.1080/09585192.2 Resource Mand
013.770783

Milgo, A.C., Namusonge, G., Kanali, C., \& Makokha, E.N. (2014). Reward and compensation as a determinant of employee commitment: A survey of KTDA tea factories in Kenya. European Journal of Business and Management, 6(15) tea factories $117-125$.

Molm, L.D., Takahashi, N., \& Peterson, G. (2000). Risk and trust in social exchange: An experimental test of a classical proposition. American Journal of Sociology, 105(5) experimental test of a classical proposition. Am

Mujtaba, B.G., \& Shuaib, S. (2010). An equitable total rewards approach to pay for performance management. Journal of Management Policy and Practice, 11(4) 11-21.

Nazir, S., Qun, W., Hui, L., \& Shafi, A. (2018). Influence of social exchange relationships on affective commitment and innovative behavior: Role of perceived organizational support. Sustainability, 10(12), 4418. https://doi.org/10.3390/ su10124418

Nazir, S., Shafi, A., Qun, W., Nazir, N., \& Tran, Q.D. (2016). Influence of organizationa rewards on organizational commitment and turnover intentions. Employee Relations, 38(4), 596-619. https://doi.org/10.1108/ER-12-2014-0150

Nehmeh, R. (2009). What is organizational commitment, why should managers wan it in their workforce and is there any cost effective way to secure it. Swiss Management Centre Working Paper, 5, 1-11. Retrieved from https://www. smcuniversity.com/working papers/Ranya_Nehmeh_-_What_is_Organizational commitment,_why_should_managers_want_it_in_their_workforce_and_is there_any_cost_effective_way_to_secure_it.pdf

Nunkoo, R. (2016). Toward a more comprehensive use of social exchange theory to study residents' attitudes to tourism. Procedia Economics and Finance, 39, 588-596.

Nwokocha, I. (2016). Managing reward strategy to enhance employee performance, retention and productivity in organizations: A general overview. International Journal of Development and Management Review, 11(1), 20-38.

Okinyi, O.M. (2015). Effect of reward practices on employee commitment in faith based health organizations in Kakamega County, Kenya. International Journal of Management Research \& Review, 5(5), 729-743.

Onyishi, A.O., Eme, O.I., \& Emeh, I.E.J. (2012). Problems of personnel management in Nigeria: The Nigerian local government system experience. Oman Chapter of Arabian Journal of Business and Management Review, 34(953), 1-14.
Osemeke, M. (2016). Identification of determinants of organizational commitment and employee job satisfaction. An International Multi-disciplinary Journal, Ethiopia, 10(2), 81-102. https://doi.org/10.4314/afrrev.v10i2.6

Othman, N. (2014). Employee performance appraisal satisfaction: The case evidence from Brunei's Civil Service. Doctoral dissertation, University of Manchester.

Oyeniyi, O. (2013). Organizational commitment and market orientation of Nigerian non-oil exporting companies. African Journal of Economic and Management Studies, 4(1), 95-108. https://doi.org/10.1108/20400701311303177

Paşaoğlu, D. (2015). Analysis of the relationship between human resource management practices and organizational commitment from a strategic perspective: Findings from the banking industry. Procedia-Social and Behavioral Sciences, 207, 315-324. https://doi.org/10.1016/j.sbspro.2015.10.101

Paulsen, M. B. (2002). Evaluating teaching performance. New Directions for Institutional Research, 2002(114), 5-18. https://doi.org/10.1002/ir.42

Permarupan, P.Y., Al-Mamun, A., Saufi, R.A., \& Zainol, N.R.B. (2013). Organizational climate on employees' work passion: A review. Canadian Social Science, 9(4), 63-68. https://doi.org/10.3968/j.css.1923669720130904.2612

Pettijohn, C.E., Pettijohn, L.S., \& Taylor, A.J. (2000). Research note: An exploratory analysis of salesperson perceptions of the criteria used in performance appraisals, job satisfaction, and organizational commitment. Journal of Personal Selling \& joles Management, 20(2), 77-80. https://doi.org/10.1080/08853134.2000. Sales Manag
10754226

Pitt, L.F., Foreman, S.K., \& Bromfield, D. (1995). Organizational commitment and service delivery: Evidence from an industrial setting in the UK. International Journal of Human Resource Management, 6(2), 369-389.

Sabatelli, R.M., Lee, H., \& Ripoll-Núñez, K. (2018). Placing the social exchange framework in an ecological context. Journal of Family Theory \& Review, 10(1), $32-48$

Salami, S.O. (2008). Demographic and psychological factors predicting organizational commitment among industrial workers. The Anthropologist, 10(1), 31-38. https:// doi.org/10.1080/09720073.2008.11891026

Saleem, S. (2011). The impact of financial incentives on employees' commitment. European Journal of Business and Management, 3(4), 258-266.

Sam-Okere, J., \& Agbeniga, F.I. (2014). Training as capacity development for effectiveness and productivity of lower cadre employees of local governments. Journal of Research and Development, 2(3), 1-10.

Saturno, P.J., Palmer, R.H., \& Gascón, J.J. (1999). Physician attitudes, self-estimated performance and actual compliance with locally peer-defined quality evaluation criteria. International Journal for Quality in Health Care, 11(6), 487-496. https:// criteria. International Journal for
doi.org/10.1093/intahc/11.6.487

Scott, H.K., \& Cogburn, M. (2017). Behavior modification. In StatPearls [Internet] StatPearls Publishing. Retrieved June from https://www.ncbi.nlm.nih.gov/books/ NBK459285/

Seniwoliba, J.A. (2014). Assessing the performance appraisal concept of the Loca Government Service in Ghana. African Journal of Business Management, 8(15), 599-611. https://doi.org/10.5897/AJBM2013.7210

Shen, J. (2004). International performance appraisals: Policies, practices and determinants in the case of Chinese multinational companies. International Journal of Manpower, 25(6), 547-563. https://doi.org/10.1108/01437720410560442

Simmons, R. (2015). Constraints on evidence-based policy: Insights from government practices. Building research \& information, 43(4), 407-419.

Šišinački, A., Dobiš, B., \& Šišinački, J. (2017). Successful organizations driven by employee performance evaluation. Obrazovanje za poduzetništvo-E4E: znanstveno stručni časopis o obrazovanju za poduzetništvo, 7(2), 189-204.

Skinner, B. F. 1969. Contingencies of reinforcement. New York: Appleton-CenturyCrofts.

Smyth, I., \& Zimba, C. (2019). An investigation into apprenticeship completion and retention in Northern Ireland: A social exchange perspective. International Journa of Training and Development, 23(1), 89-115. https://doi.org/10.1111/ijtd.12146

Sungu, L.J., Weng, Q.D., \& Kitule, J.A. (2019). When organizational support yields both performance and satisfaction: The role of performance ability in the lens of social exchange theory. Personnel Review, 48(6), 1410-1428. https://doi.org/10.1108/ PR-10-2018-0402

Taba, M.I. (2018). Mediating effect of work performance and organizational commitment in the relationship between reward system and employees' work satisfaction. Journal of Management Development, 37(1), 65-75. https://doi. org/10.1108/JMD-11-2016-0256

Tokay, Ö., \& Eyupoglu, S.Z. (2018). Employee perceptions of organisational democracy and its influence on organisational citizenship behaviour. South African Journal of Business Management, 49(1), 1-9. https://doi.org/10.4102/sajbm.v49i1.397

Tsai, J.C.A., \& Kang, T.C. (2019). Reciprocal intention in knowledge seeking: Examining social exchange theory in an online professional community. International Journal of Information Management, 48, 161-174. https://doi.org/10.1016/j.ijinfomgt. 2019.02.008

Tsede, O. A., \& Kutin, E. (2013). Total reward concept: A key motivational tool for corporate Ghana. Business and Economic Research, 3(2), 173-188. https://doi org/10.1007/978-3-319-31816-5_3548-1

Van der Hoek, M., Groeneveld, S., \& Kuipers, B. (2018). Goal setting in teams: Goal clarity and team performance in the public sector. Review of public personnel administration, 38(4), 472-493. https://doi.org/10.1177\%2F0734371X 16682815

Venclová, K., Salková, A., \& Kolácková, G. (2013). Identification of employee performance appraisal methods in agricultural organizations. Journal of Competitiveness, 5(2), 20-36. https://doi.org/10.7441/joc.2013.02.02 
Verbeeten, F. H. (2008). Performance management practices in public sector organizations. Accounting, Auditing \& Accountability Journal, 21(3), 427-454. organizations. Accounting, Auditing \& Accoun
https://doi.org/10.1108/09513570810863996

Wikhamn, W., \& Hall, A.T. (2012). Social exchange in a Swedish work environment. International Journal of Business and Social Science, 3(23), 56-64.
Wrzesniewski, A., McCauley, C., Rozin, P., \& Schwartz, B. (1997). Jobs, careers, and callings: People's relations to their work. Journal of Research in Personality, 31(1), 21-33. https://doi.org/10.1006/jrpe.1997.2162

Zafirovski, M. (2005). Social exchange theory under scrutiny: A positive critique of its economic-behaviorist formulations. Electronic Journal of Sociology, 2(2), 1-40. 